ASSOCIATE EDITORS (Continued)

Ellen R.M. Druffel

Department of Earth System Sciences, PSRF-207 University of California, Irvine, CA 92717 (714) 725-2116

Internet: druffel@bro.ps.uci.edu

Donald B. Olson RSMAS

University of Miam

Miami, FL 33149 USA

(305) $361-4074$; D.OLSON.RSMAS

Internet: don@loquat.rsmas.miami.edu

Makoto Omori

Department of Aquatic Biosciences Tokyo University of Fisheries 4-5-7, Konan, Minato-ku, Tokyo, Japan (03)471-1251

Louis M. Prieur

Laboratoire de Physique et Chimie Marines Observatoire Oceanologique de Villefranche sur Mer BP 08 La Darse

06230 Villefranche Sur Mer, France (33) 93763739

Internet: prieur@ccrv.obs-vlfr.fr

Richard W. Spinrad

Office of Naval Research, Code 322

800 N. Quincy St.

Arlington, VA 22217 USA

(703) 696-4732; R.SPINRAD

Internet: spinrar.onrhq.onr.navy.mil

James Syvitski

Atlantic Geoscience Centre

Bedford Institute of Oceanography

Dartmouth, NS B2Y4A2, Canada (902) 426-6867

Peter Wadhams

Scott Polar Research Institute

University of Cambridge Lensfield Road

Cambridge CB2 1ER England 223-336542

Internet: pw11@phx.cam.ac.uk PRINTER Lancaster Press

Lancaster, PA USA

\title{
Message From Outgoing President
}

$\mathrm{M}$ Y TERM AS PRESIDENT of The Oceanography Society expired in June 1994, and now I take the position of Past-President. I have the unique distinction of being not only the first President-Elect of our newly formed society, but also the first Past-President of the Society, as Jim Baker resigned from the TOS Council when he was appointed NOAA Administrator. It has been a wonderful and rewarding experience being associated with TOS during these formative years; I thank the membership for giving me the opportunity. I enjoyed working with the TOS Council. Our meetings are always very lively as we all realize that our precedent-setting actions determine how effectively and for how long we will serve our community. As a fledgling organization we could ill afford a mistake.

With a strong belief that the international community of ocean scientists requires and deserves a "home of its own," TOS was born in 1988 under the expert guidance of Jim Baker. We provided a magazine format and a meeting venue new to our field. The community responded positively. In those initial years we were vulnerable to pass into oblivion: if we didn't provide the correct and sufficient services we would fail; if we provided more services than our income would allow, we would fail. We had to keep our balance and we have done so. We are now carefully considering expanding services within the confines of a more secure though not ample financial position. We now have annual meetings, the thematic meetings in the spring of the odd years and topical meetings in the even years, the latter beginning with the Pacific Ocean meeting in Hawaii in July, 1994. Our magazine is produced on a more regular basis under a more efficient budget. Increasing the number of issues per year is a high priority objective.

TOS is searching for ways to better meet the needs of the international community of ocean scientists. We are always open to suggestions of how TOS could do this and in particular we appreciate offers of help in the development of new activities and the improvement of current ones. Margaret Leinen is now the TOS President, and I am confident that she will skillfully guide our continued development; we are in good hands!

Imagine, the ocean sciences now have a Society of their own! We determine its course-become part of the action.

- Arnold L. Gordon

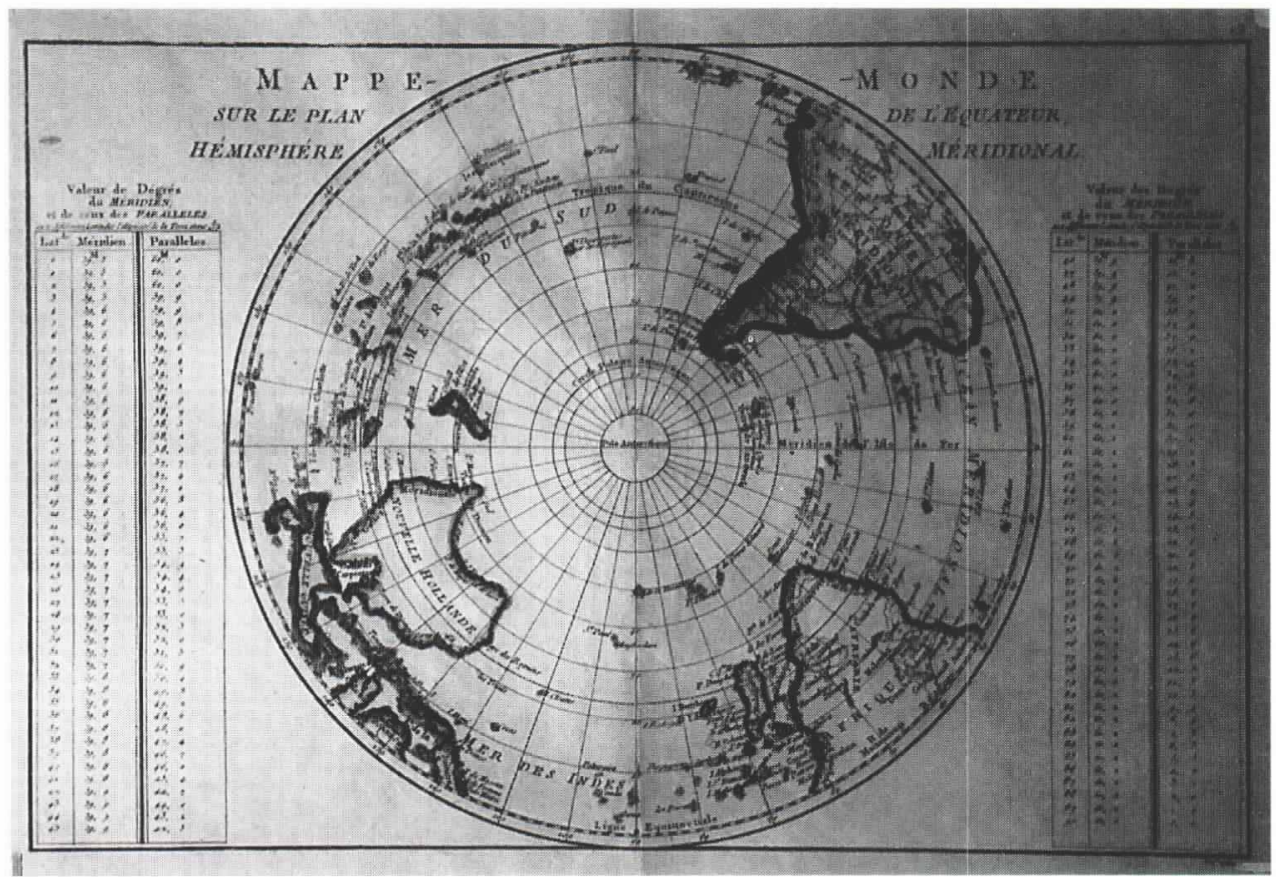

That was Arnold Gordon's response when he examined the framed chart given to him by the Council on behalf of the members. The chart is a southern hemisphere stereographic projection centered on the South Pole that is reasonably correct, save the missing Antarctic continent. Evidently Cook had already discovered the continent, but chart makers had yet to include the new discovery on the charts. 